\title{
Electrolytes, Metabolic And Acid-Base Parameters In Blood And Fluids of The Reproductive Tract During In Vivo Maturation of Bovine Oocytes
}

Omer F. Gungor

University of Connecticut

Saleh Salman

University of Connecticut

Saurav Ranjitkar

University of Connecticut

Delong Zhang

University of Connecticut

Xiuchun (Cindy) Tian ( $\nabla$ xiuchun.tian@uconn.edu )

University of Connecticut

Research Article

Keywords: iSTAT, bovine follicular, oviductal and uterine fluids, metabolites, acid-base

Posted Date: August 11th, 2021

DOI: https://doi.org/10.21203/rs.3.rs-783920/v1

License: (9) This work is licensed under a Creative Commons Attribution 4.0 International License.

Read Full License 
1

1

4

5

\section{Electrolytes, metabolic and Acid-base Parameters in Blood and Fluids of the Reproductive} Tract during in vivo Maturation of Bovine Oocytes

Omer F. Gungor ${ }^{1,2}$, Saleh Salman ${ }^{1,3}$, Saurav Ranjitkar ${ }^{1}$, Delong Zhang ${ }^{1}$, Xiuchun (Cindy) Tian ${ }^{1, *}$

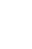

\footnotetext{
${ }^{2}$ Permanent address: Laboratory and Veterinary Assistance Services Program, Vocational School
}

${ }^{1}$ Department of Animal Science, University of Connecticut, Storrs, CT 06269, USA of Veterinary Medicine, Bolu Abant Izzet Baysal University, Mudurnu, Bolu 14800, Turkey

${ }^{3}$ Department of Animal Production, Agriculture College, Assiut University, Egypt, 71111

*Corresponding author: Xiuchun (Cindy) Tian, email: Xiuchun.tian@uconn.edu; Tel: (860) 4869087, 1390 Storrs Road, Storrs, CT 06269-4163, USA

2

Omer F. Gungor and Saleh Salman contributed equally to this work as first authors.

3

Keywords: iSTAT, bovine follicular, oviductal and uterine fluids, metabolites, acid-base 
Follicular fluid is the microenvironment that supports oocyte maturation and competence.

19 Using Abbott iSTAT1 ${ }^{\mathrm{TM}}$ and NanoDrop, we determined the dynamics of acid-base, electrolyte, 20 metabolites, and total protein in venous blood, fluids of the dominant follicle (FF), oviduct (OF), 21 and uterus (UF) during the window of oocyte maturation. Holstein heifers $(n=36)$ were 22 synchronized with $\mathrm{PGF}_{2 \alpha}$ on Days -11 and 0, CIDR during Days -6 to 1 , and GnRH given on Day 232 after $2^{\text {nd }}$ PG. Samples were collected at $24 \mathrm{~h}, 48 \mathrm{~h}, 60 \mathrm{~h}, 72 \mathrm{~h}$, and $78 \mathrm{~h}$ after $2^{\text {nd }}$ PG. Most 24 electrolytes analyzed, $\mathrm{Cl}^{-}, \mathrm{K}^{+}$, and $\mathrm{Ca}^{2+}$ were significantly affected in blood and $\mathrm{FF}(P<0.05)$ by 25 CIDR removal. Similarly, $\mathrm{Cl}^{-}$and $\mathrm{Na}^{+}$also significantly changed in OF and UF across time. 26 Glucose, lactate, and creatinine significantly changed across time points in FF compared to blood. 27 Moreover, $\mathrm{pO}_{2}, \mathrm{pCO}_{2}, \mathrm{TCO}_{2}$, and $\mathrm{pH}$ significantly changed across time in $\mathrm{FF}$. Most parameters 28 were not significantly correlated between blood and FF across time points except for glucose, $\mathrm{Cl}^{-}$ 29 and creatinine. Furthermore, $\mathrm{pO}_{2}$ in $\mathrm{FF}$ was nearly $3 \mathrm{X}$ higher than blood, suggesting low $\mathrm{O}_{2}$ during 30 in vitro maturation is inappropriate. In conclusion, components of the follicular fluid undergo 31 major changes during the window of oocyte maturation. 
Bovine embryos from genetically elite animals have been produced by both in vivo and in vitro approaches for rapid genetic improvements. In vivo embryos are of better quality but are 35 more expensive. For instance, the cost of in vivo embryos generated using X-sorted semen is 2.5 times higher than that of their in vitro counterparts ${ }^{1}$. While less costly, in vitro embryos are of

37 lower quality, contain fewer cells, survive cryopreservation poorly, and are less fertile ${ }^{2,3}$. The average pregnancy rate from in vivo embryos is more than $60 \%$, while it is only around $40 \%$ from 39 in vitro embryos ${ }^{4}$. The poor in vitro environment in which the oocytes are matured, and embryos 40 are cultured is the culprit of these differences. While ample research has focused on improving the 41 embryo culture media, in vitro blastocyst development continues to linger around $20-30 \%{ }^{5}$. The 42 maturation condition of oocytes, however, appears to be more consequential to embryo 43 development. Smith et al. $^{6}$ reported a $75 \%$ blastocyst rate from oocytes matured in vivo yet 44 cultured in vitro. Similarly, Yuan et al. ${ }^{7}$ reported a 4-fold increase in live birth rates of cloned pigs 45 by improving oocyte maturation medium alone. While the currently used oocyte maturation 46 condition regularly produces $75-85 \%$ nuclear maturation rates, the cytoplasmic maturation 47 remains poor ${ }^{5}$.

Therefore, the determination of the in vivo microenvironments supporting oocyte 49 maturation and embryo development is important in improving embryo production in vitro. Oocyte 50 maturation and early embryo development occur in the ovarian follicle and oviduct/uterus, 51 respectively ${ }^{8-10}$. The oviduct and uterine environments, also play vital roles in sperm 52 transportation, reservoir, and oocyte fertilization ${ }^{11}$. The fluids of the follicle (FF), oviduct (OF), 53 and uterus (UF) are constituted from a combination of selective serum transudate and locally 54 produced molecules, secreted from the uterine, oviduct epithelial, and granulosa cells ${ }^{8,12}$. 
Numerous prior studies have reported electrolytes, metabolic and acid-base parameters in

56 bovine blood and follicular and a few on oviductal, and uterine fluids ${ }^{8,9,12}$. However, the vast

57 majority of them used slaughterhouse materials ${ }^{13}$. Among the few that did conduct a controlled

58 study with clearly defined reproductive status, samples were taken from different days of the

59 estrous cycle. No reports to date followed the progression of changes in these fluids during the

60 specific window of time in which the oocytes mature in vivo.

The Abbott point-of-care handheld blood analyzer, iSTAT, is a convenient device for

62 measurements of tissue fluids. A few recent studies have reported its adaption in the bovine blood

63 and tissue fluids ${ }^{14,15,16}$. In this study, we collected serum, follicular, oviductal, and uterine fluids

64 in Holstein heifers $24 \mathrm{~h}$ before and after the $\mathrm{LH}$ surge, during which the follicles undergo final

65 development, and the oocyte matures. The dynamics of components of these fluids were

66 determined by iSTAT. We found significant changes in most parameters studied. The data

67 obtained here are good references to improve the in vitro oocyte maturation conditions. 


\section{MATERIALS AND METHODS}

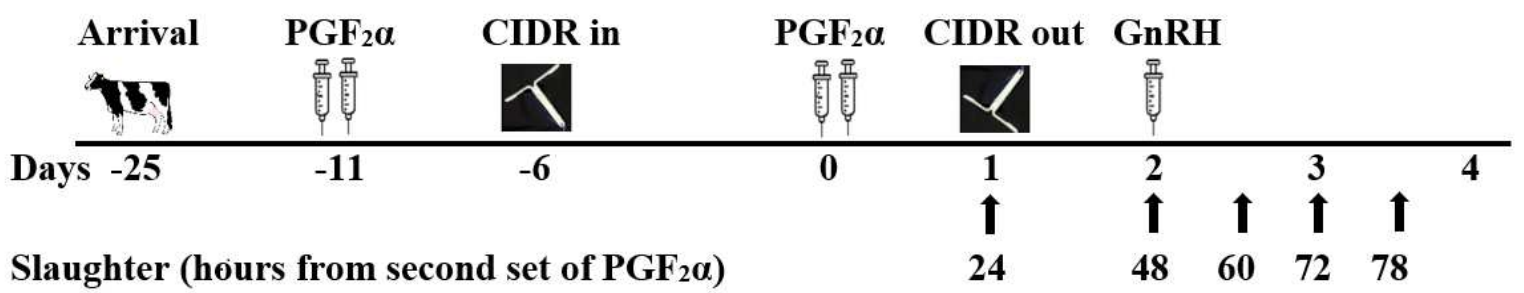

Fig. 1. Schematic diagram of animal handling, treatment, and tissue collection (not drawn to

\section{Animals and estrus synchronization}

The present study was approved by the Institutional Animal Care and Use Committee (IACUC) at the University of Connecticut. The study was reported in accordance with ARRIVE guidelines and under IACUC supervision. All methods were performed in accordance with the relevant guidelines and regulations. A total of 36 reproductively normal and healthy nulliparous Holstein heifers approximately $15.29 \pm 0.54$ months of age and $417.03 \pm 8.27 \mathrm{~kg}$ in weight were purchased from local farms. Once arrived, the animals were given a 14-day acclimation and quarantine time before treatments. The animals were then allocated to one of six groups ( $n=6 /$ group) for reproductive tract collection.

Slaughter (hours from second set of $\mathrm{PGF}_{2} \alpha$ )

$\begin{array}{lllll}24 & 48 & 60 & 72 & 78\end{array}$

To synchronize estrus, a protocol reported by Bo et al. ${ }^{17}$ was modified and the animals were treated as shown in Fig. 1. After the 14-day quarantine period animals were given two sets of two prostaglandin $\mathrm{F}_{2} \alpha\left(\mathrm{PGF}_{2} \alpha ; 2 \mathrm{ml}\right.$ of Lutalyse HighCon Injection, Dinoprost Tromethamine injection, $12.5 \mathrm{mg} / \mathrm{ml}$ ) intramuscularly injections eleven days apart on Days -11 and 0. A vaginal CIDR device (controlled internal drug release; EAZI-Breed CIDR Cattle Insert) containing 1.38 grams of progesterone was inserted on Day -6 and removed on Day 1 ( $24 \mathrm{~h}$ after the first $\mathrm{PGF}_{2} \alpha$ injection of the second set). On Day 2 or $48 \mathrm{~h}$ after $\mathrm{PGF}_{2} \alpha$, a single dose of $100 \mu \mathrm{g}$ gonadotrophin- 
86 releasing hormone $(\mathrm{GnRH} ; 2 \mathrm{ml}$ of Factrel injection, $50 \mu \mathrm{g} / \mathrm{ml})$ was given intramuscularly to

87 induce the LH surge. This protocol ensures tight estrus synchronization through rapid progesterone

88 decline (after CIDR removal) and precise LH surge (induced by GnRH).

After quarantine, jugular venous blood samples were collected daily into silicone-coated

90

91

92

93

94 97 for further processing.

vacutainer tubes without anti-coagulants. The samples were allowed to clot and then centrifuged at $2,500 \mathrm{~g}$ for $15 \mathrm{~min}$ in a refrigerated centrifuge $\left(4^{\circ} \mathrm{C}\right)$. The serum was stored at $-80^{\circ} \mathrm{C}$ until

analysis. Daily ultrasound of the ovaries using an Aloka 500 ultrasound machine equipped with a linear probe of $5 \mathrm{MHz}$ was conducted starting from the second set of $\mathrm{PGF}_{2} \alpha$ injections (Day 0). To avoid manual ovulation, ultrasound was not conducted on the day of slaughter.

The animals were sacrificed at $24,48,60,72$, and $78 \mathrm{~h}$ after the first $\mathrm{PGF}_{2} \alpha$ injection of the second set (Day 0), and reproductive tracts were transported at ambient temperature to the lab

\section{Follicular, oviduct and uterine fluid collection}

Follicular fluids from the largest growing follicles were aspirated using a syringe fitted with an 18-Gauge needle. The fluids were centrifuged at $1,000 \mathrm{~g}$ for $5 \mathrm{~min}$ to remove granulosa cells then analysis was done before storing at $-80^{\circ} \mathrm{C}$. Theca cell layer and granulosa cells of the follicle were examined as described previously ${ }^{18}$. Briefly, the collapsed follicle was placed in PBS and rinsed in a new petri dish. Whereupon the follicle was cut into quarters with scissors, and theca and granulosa cells layer were peeled off from the rest of the follicle wall. The granulosa cells 105 were gently scraped using a fine glass needle under the stereomicroscope. The dominant status of 106 the follicles was verified by vascularization of the theca layer and the abundance and morphology 107 of granulosa cells. 
To collect fluids from the oviduct and uterus, the uterotubal junction and the uterinecervical junction were first tied to avoid fluid movements. The oviducts were catheterized from the fimbriae end and oviductal fluid was collected into an Eppendorf tube with gentle massage.

111 The cornu uteri were catheterized from the uterotubal junction and fluid was collected into an 112 Eppendorf tube by gently massaging the cornu uterus.

Due to the small amounts, the fluids from the left and right oviducts and uterine horns were

114 combined. Previous studies of the two sides of the reproductive tracts reported no difference

115 between fluids ipsilateral or contralateral to the side of ovulation ${ }^{8,19,20}$. The OF and UF samples 116 were centrifuged at $2,000 \mathrm{~g}$ for 2 minutes in a refrigerated centrifuge $\left(4^{\circ} \mathrm{C}\right)$ and then analysis was 117 done before storing at $-80^{\circ} \mathrm{C}$.

\section{Measurements of total protein, gases, acid-base parameters, electrolytes, and metabolites}

The NanoDrop $1000^{\mathrm{TM}}$ was used to measure the total protein in both the serum and FF. The handheld iSTAT1 analyzer from Abbott together with the CG4+ and CHEM8+ cartridges

121 were used on all fluids when sufficient amounts were available. CG4+ was designed to determine $122 \mathrm{pH}, \mathrm{pO}_{2}, \mathrm{pCO}_{2} \mathrm{TCO}_{2}, \mathrm{HCO}_{3}{ }^{-}$, base excess (BE), saturated oxygen saturation $\left(\mathrm{sO}_{2}\right)$, and lactate. 123 The CHEM8+ determines sodium $\left(\mathrm{Na}^{+}\right)$, potassium $\left(\mathrm{K}^{+}\right)$, chloride $\left(\mathrm{Cl}^{-}\right)$, ionized calcium $\left(\mathrm{iCa}^{2+}\right)$, $124 \mathrm{TCO}_{2}$, glucose, urea nitrogen (BUN)/urea, creatinine, hematocrit, and hemoglobin. The iSTAT 125 device was designed for use with human blood but has been used off-label in other species and 126 tissue fluids ${ }^{15,16}$. The caveat of this off-label use is that the cartridges were calibrated to the ranges 127 of parameters in humans. Animal fluids may contain levels higher or lower than the maximum or 128 minimum detection limits.

\section{Statistical analysis}


We used $\mathrm{R}^{\odot}$ software ${ }^{21}$ to run one-way ANOVA across different time points after $\mathrm{PGF}_{2 \alpha}$ 131 and significance was set at $P<0.05$. We also used Fisher's Least Significant Difference (LSD) for 132 pairwise comparisons of different time points. Linear regression and Pearson correlation were used 133 to evaluate the relationship between blood (predictor) and FF (outcome) values of different 134 parameters across time. The goodness of fit was evaluated by Adjusted $\mathrm{R}^{2}$ values and the 135 regression coefficients (slopes) were used to determine the significance of correlation. 


\section{Estrus Synchronization}

All animals had one growing large follicle and a CL was seen through ultrasound examination (data not shown) before and after $\mathrm{PGF}_{2 \alpha}$ injection and at the time of tissue collection. Follicles collected at $78 \mathrm{~h}$ post-PGF ${ }_{2 \alpha}$ ovulated in 4 out of 6 animals and their FF were not available, thus we are only reporting the analysis of the remaining 2 animals in this group. From the appearance of the theca layers and ovulation crowns, the animals likely ovulated just one or two hours before collection. Since none of the animals ovulated at the 72-h point, this synchronization protocol induced tight ovulation which likely occurred within an hour or two of $75 \mathrm{~h}$ after $\mathrm{PGF}_{2 \alpha}$ injection (Fig. 2). Because we expected the LH surge to occur $2 \mathrm{~h}$ after the GnRH injection (given at $48 \mathrm{~h}$ post $\mathrm{PGF}_{2 \alpha}$ ), ovulation induced through this protocol, therefore, occurred between 22 and $28 \mathrm{~h}$ after the LH surge. This is a much tighter synchronization and earlier ovulation by 3-5 hours than the original report of an average of $\sim 79.1 \mathrm{~h}^{17}$ and range of $64-96 \mathrm{~h}$ after $\mathrm{PGF}_{2 \alpha}$. It is worthy to mention that our study utilized Holstein dairy heifers, yet Bo et $\mathrm{al}^{17}$. used a mixture of Angus/Brangus cows and heifers.

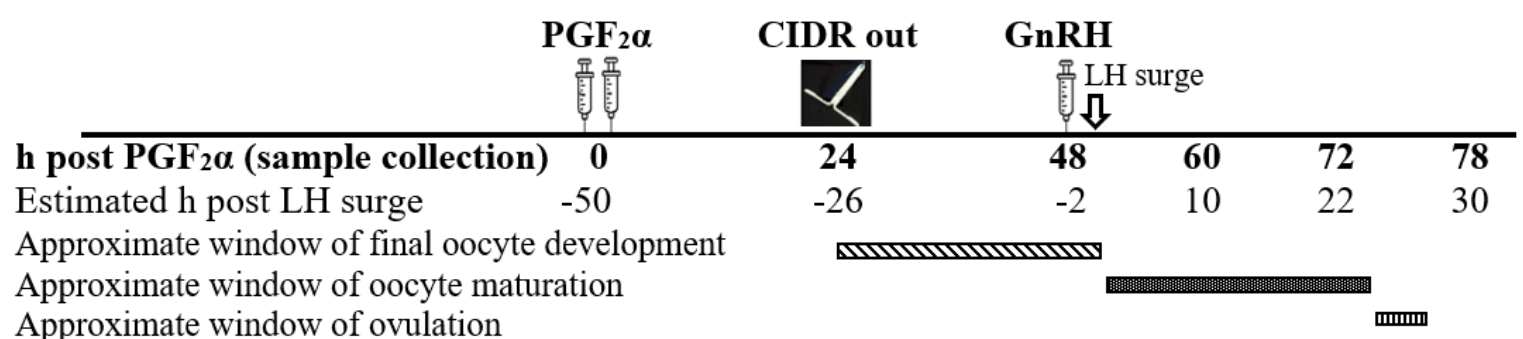

Fig 2. Schematic diagram of treatments, the estimated timing of LH surge, and windows of in vivo oocyte development, maturation, and follicle ovulation (not drawn to scale; besides blood, no other samples were collected at the time of $\mathrm{PGF}_{2 \alpha}$ injection). 


\section{Microenvironment of the developing and maturing oocytes (FF) and blood}

Changes in the microenvironment of oocytes during the periods of final oocyte development and resumption of meiosis were monitored in follicular fluids between $\sim 26 \mathrm{~h}$ before and $30 \mathrm{~h}$ after the LH surge, respectively. Jugular venous blood is much easier to collected and used to reveal whether blood parameters could predict the follicular microenvironment.

While the FF is mainly derived from the blood serum, most parameters were very different between these two fluids. For example, total protein concentrations in serum averaged $87.80 \pm$ $9.50 \mathrm{mg} / \mathrm{ml}$ and was unaffected by luteolysis (Fig. 3). This was expected as serum protein levels should not dramatically change according to ovarian development. Follicular fluid, however, contained a much less total protein with an overall mean of $51.00 \pm 12.11 \mathrm{mg} / \mathrm{ml}$. Furthermore, total protein changed with the progression of follicular development $(P=0.041)$, reaching the highest level of $57.79 \pm 5.20 \mathrm{mg} / \mathrm{ml}$ at the $72 \mathrm{~h}$ time point. This higher level of protein may represent the secretion from the larger number of granulosa cells as follicles approach ovulation ${ }^{18}$.

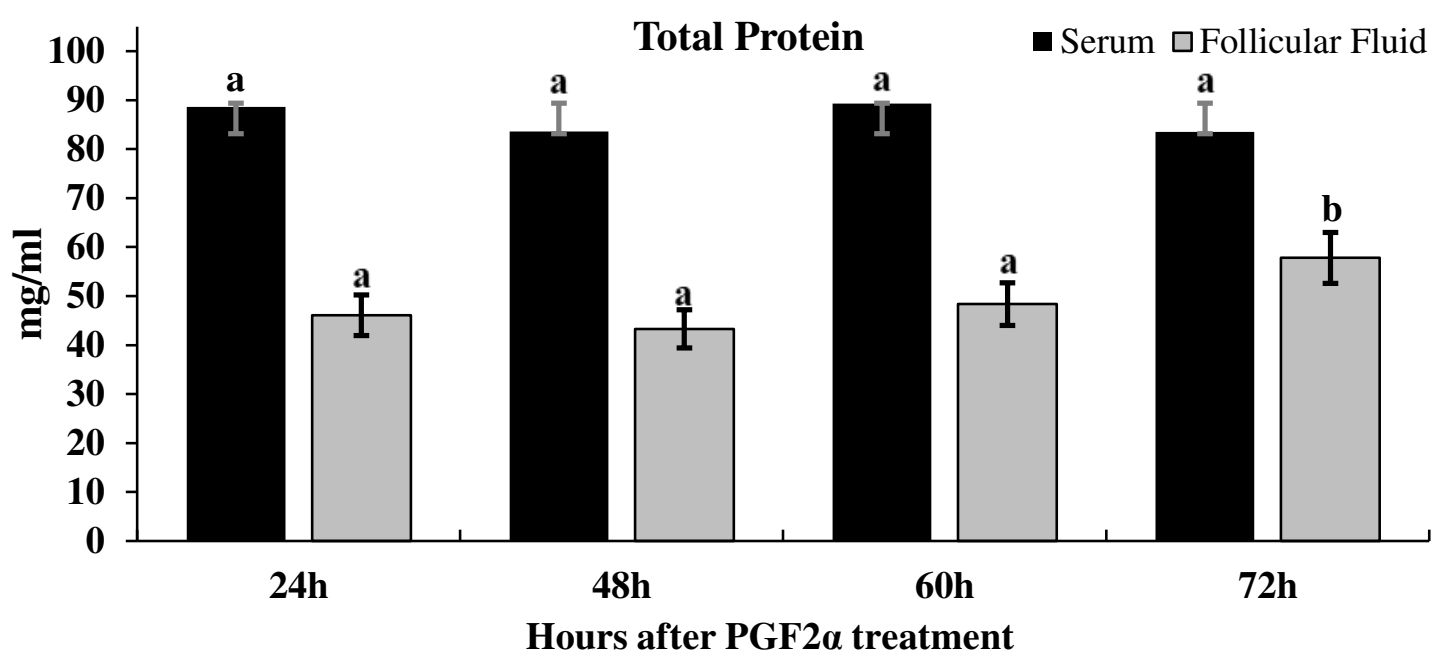

Fig 3. Total protein concentrations in serum (black bars) and follicular fluids (gray bars) across different time points after $\mathrm{PGF}_{2 \alpha}$. Significant differences across time were only seen in follicular fluid $(P=0.041)$. 

$P$-value of $0.037,0.014$, and 0.0008 , respectively, but $\mathrm{Na}^{+}$with $P$-value of 0.079 was not significant. Surprisingly, FF parameters $\left(\mathrm{K}^{+}, \mathrm{Na}^{+}\right.$, and $\left.\mathrm{Ca}^{2+}\right)$ did not change significantly across

167 time with $P$-value of $0.099,0.079$, and 0.096 , respectively, and $\mathrm{Cl}^{-}$was not significant with $P$ -

168 value of 0.143 (Fig. 4). Interestingly all electrolytes in FF underwent major changes between 24

169 and $48 \mathrm{~h}$ (pairwise comparison $P<0.05$ ) after $\mathrm{PGF}_{2 \alpha}$ when luteolysis/CIDR removal occurred 170 which should cause a drastic and rapid decline in progesterone levels, but not significant changes 171 across all time points. In $\mathrm{FF}, \mathrm{Cl}^{-}$and $\mathrm{K}^{+}$significantly decreased, while $\mathrm{Ca}^{2+}$ and $\mathrm{Na}^{+}$increased. 172 Most electrolytes in FF, however, attempted to return to pre-luteolysis levels by 60h post-PGF $2 \alpha$.

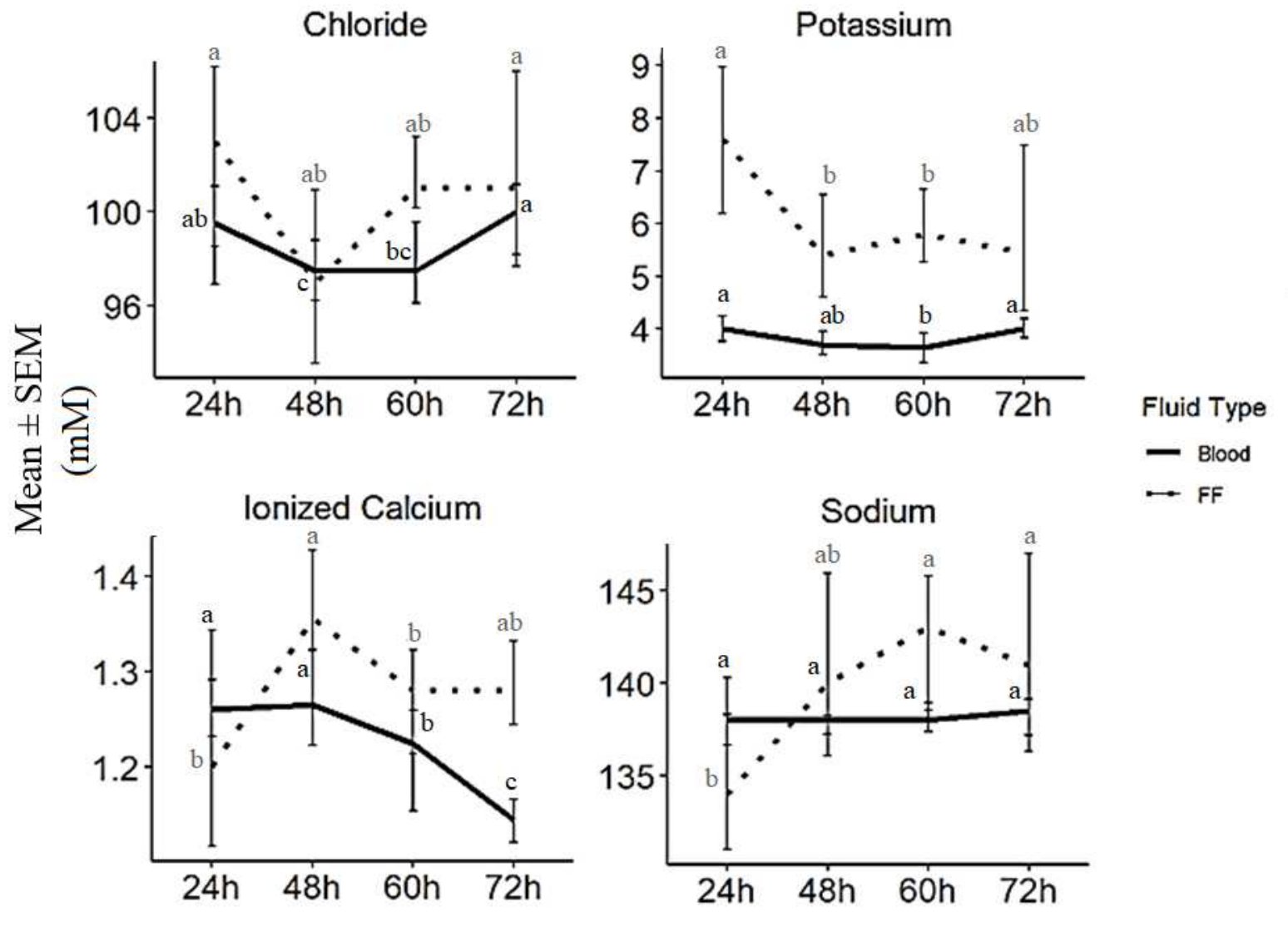

Hours after PGF2 $\alpha$ treatment

Fig 4. Electrolytes in blood (solid lines) and FF (dotted lines) across different time points after $\mathrm{PGF}_{2 \alpha}$ injection. In Blood, $P$-value $\left(\mathrm{Na}^{+}=0.079, \mathrm{Cl}^{-}=0.037, \mathrm{~K}^{+}=0.014, \mathrm{Ca}^{2+}=0.0008\right)$, and $\mathrm{FF}\left(\mathrm{K}^{+}=0.099\right.$, $\mathrm{Na}^{+}=0.079, \mathrm{Ca}^{2+}=0.096$ and $\mathrm{Cl}^{-}=0.143$ ). 


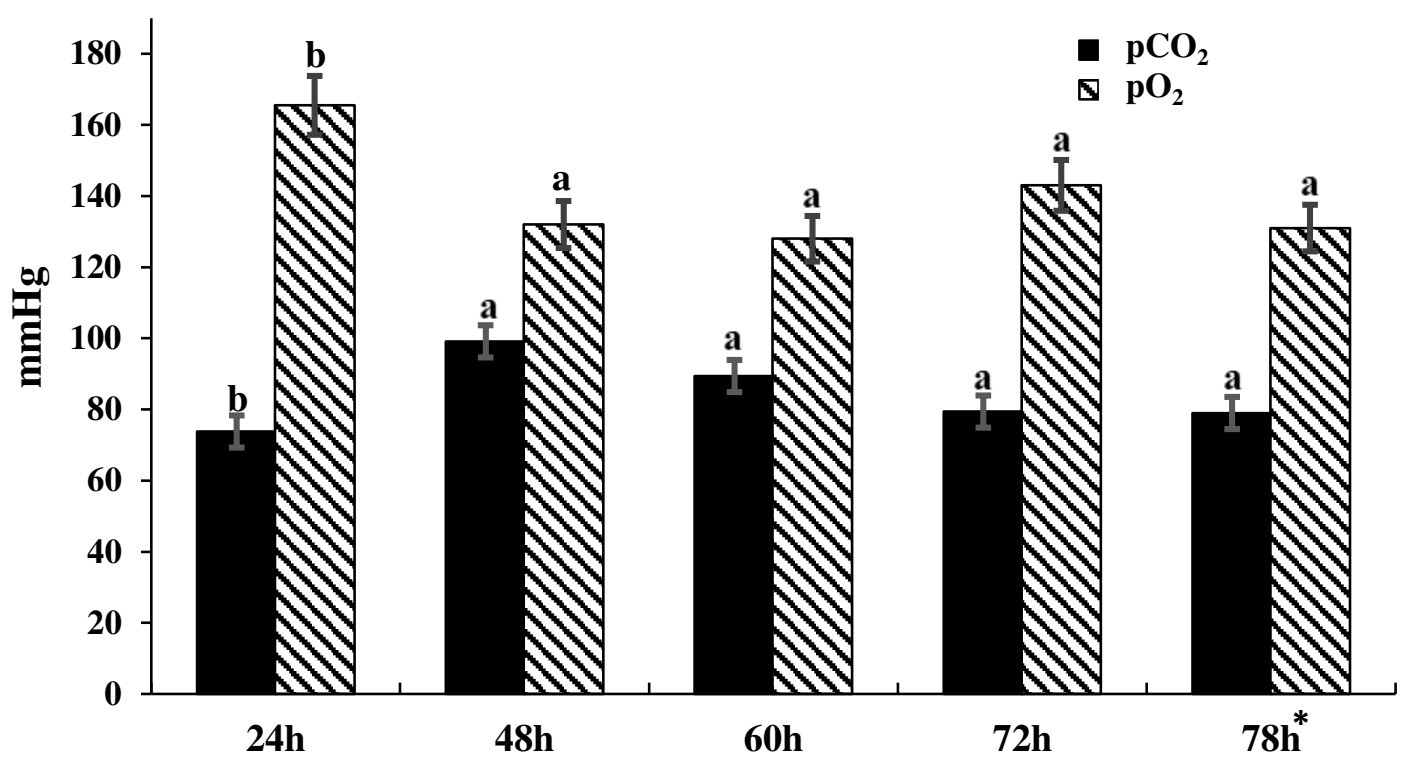

Fig 5. Partial pressures of oxygen $\left(\mathrm{pO}_{2}\right)(P$-value $=0.0069)$ and carbon dioxide $\left(\mathrm{pCO}_{2}\right)(P$-value $=$ 0.336) in FF of different time points after $\mathrm{PGF}_{2 \alpha}$ injection. The $*$ is donated to data from 2 animals, and the rest of the animals ovulated.

Tissue fluid gases are important for $\mathrm{pH}$ maintenance and metabolism. The $\mathrm{O}_{2}$ partial 175 pressure in FF (Fig. 5) significantly decreased $(P$-value $=0.0069)$ upon luteolysis and stabilized 176 thereafter. These changes in $\mathrm{pO}_{2}$ may be a result of the accumulation of more granulosa cells and 177 therefore higher metabolism and consumption and subsequently the gaining of vascularization by 178 the theca layer. Nevertheless, the follicular antrum is an avascular compartment, yet $\mathrm{pO}_{2}$ level was 179 similar to that in arterial blood ${ }^{22,23}$, suggesting active mechanisms for maintaining this high $\mathrm{O}_{2}$ 180 level. This observation suggests that in vitro oocyte development and maturation should employ 181 arterial blood level of $\mathrm{O}_{2}$ as opposed to the lower $\mathrm{O}_{2}$ tension of 5\%. The increase in $\mathrm{pCO}_{2}$ upon 182 luteolysis/CIDR removal was not significant $(P$-value $=0.336)$ is compatible with the decrease in $183 \mathrm{pO}_{2}$, and a result of increased metabolism. As expected, blood $\mathrm{pO}_{2}$ and $\mathrm{pCO}_{2}$ were not significant 184 with p-value of 0.257 and 0.198 , respectively. 

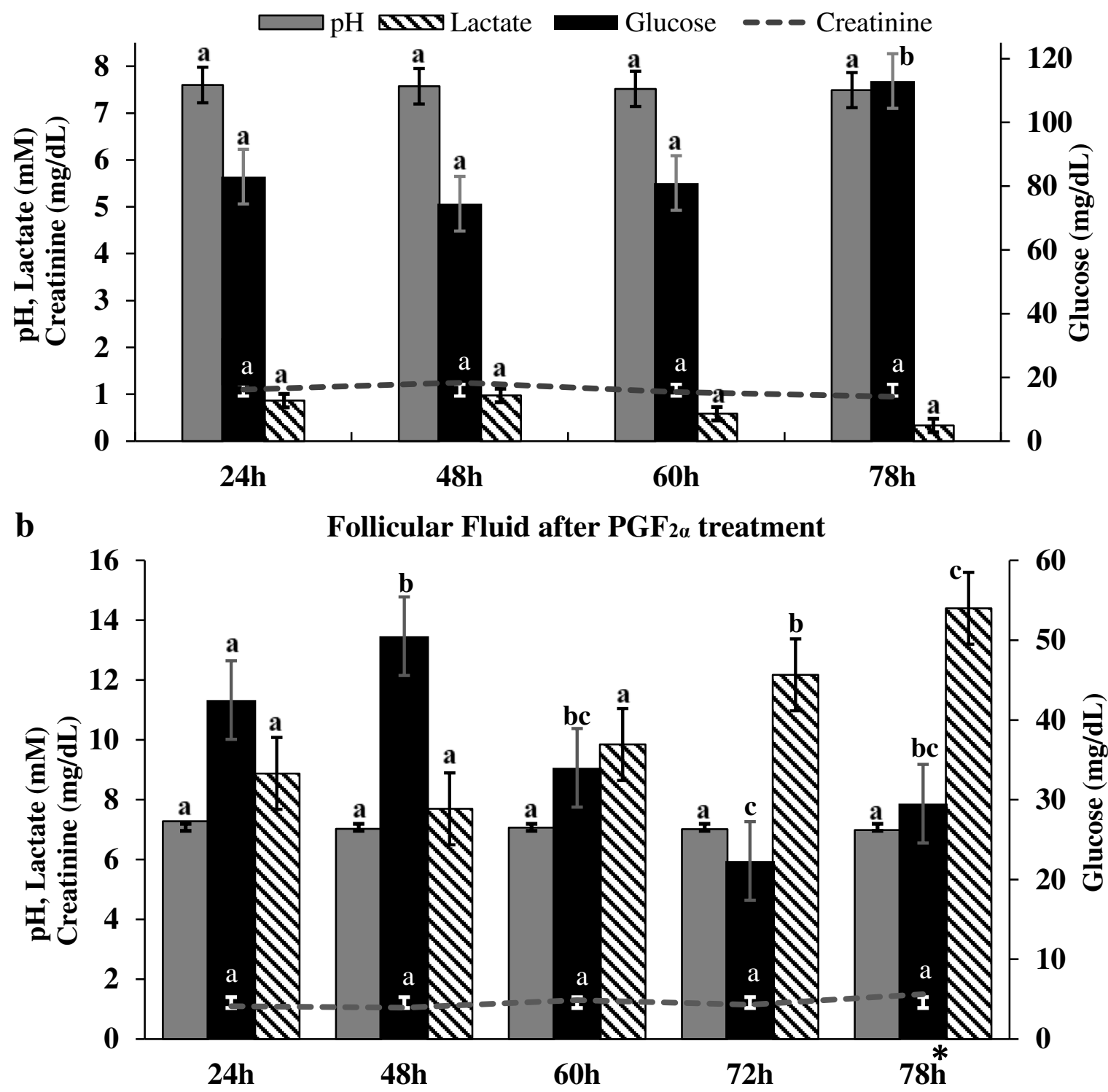

Fig 6. Blood (a) and FF (b) metabolites across time points after $\mathrm{PGF}_{2 \alpha}$ injection. * Is donated to data from 2 animals, and the rest of the animals ovulated. The significant results are FF glucose $(P=0.01)$, creatinine $(P=0.026)$, and Lactate $(P=0.001)$. The $\mathrm{pH}$ did not significantly change in blood $P=0.078$ and FF $P=0.067$. Blood glucose or lactate did not significantly change. Creatinine changed significantly in both Blood $(P=0.006)$ and $\mathrm{FF}(P=0.026)$.

As expected, the blood $\mathrm{pH}$ was well-maintained across treatment times (Fig. 6a). However,

187 the $\mathrm{pH}$ in FF (Fig. 6b) significantly decreased as follicles approached ovulation $(P=0.028)$. Blood

188 glucose, lactate, and creatinine also did not significantly change across time (Fig. 6a). Significant 

with the increased metabolic activities as follicles continued the trajectory toward ovulation.

191 During 24 to $78 \mathrm{~h}$ post-PGF injection, glucose significantly decreased from 38.40 to $25.83 \mathrm{mg} / \mathrm{dL}$ $(P=0.01)$ due to higher metabolism. The reduction in glucose resulted in a near doubling of lactate, from 7.81 to $12.19 \mathrm{mM}$, and highly significant $(P=0.003)$ across treatment groups.
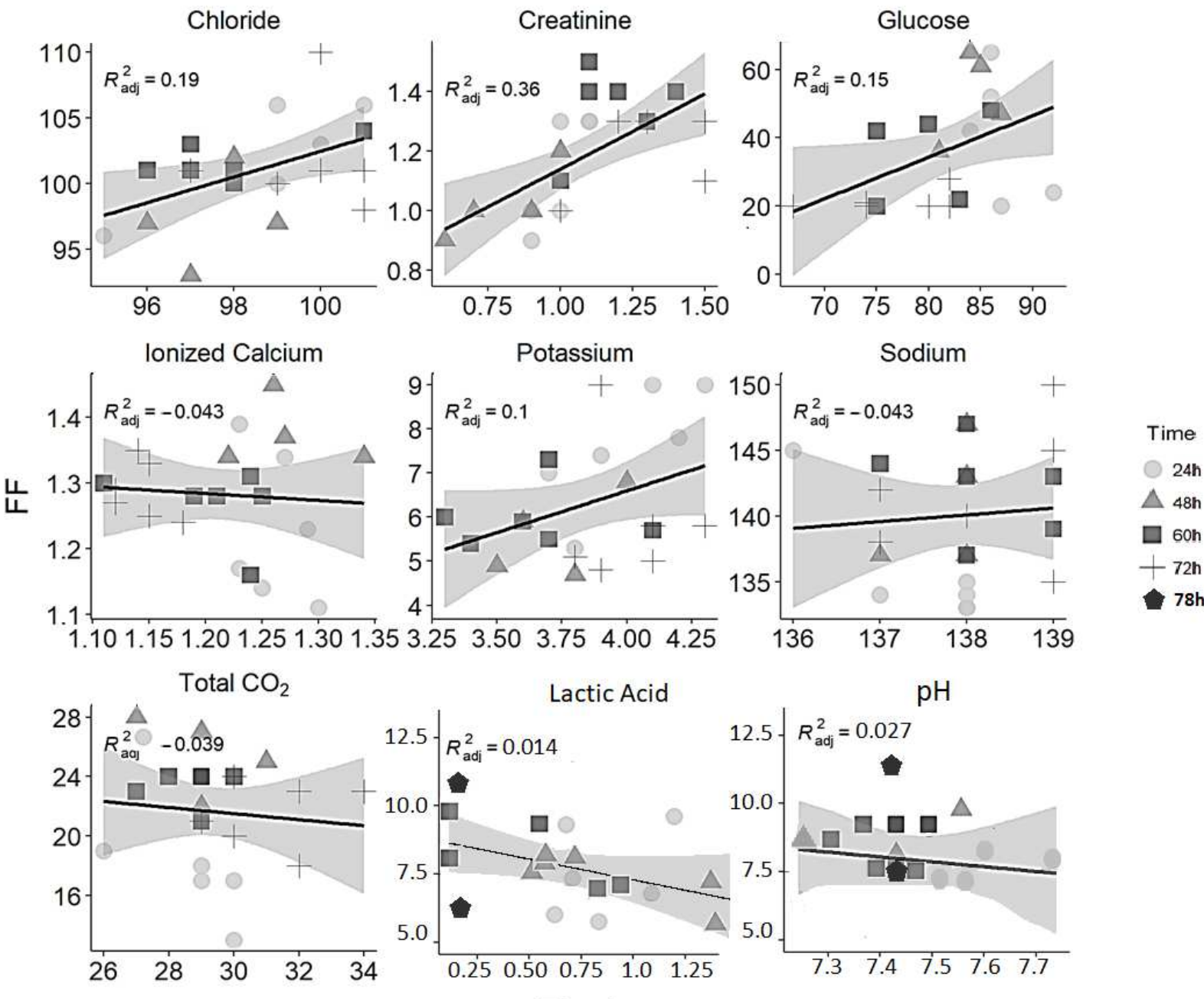

Blood

Fig 7. Correlations between blood (X-axis) and FF (Y-axis) in nine parameters across time points. The black line and the gray area in each plot represent the regression line and confidence intervals of the correlations, respectively. The intercepts are; $\mathrm{Cl}^{-} 0.98(P=0.02)$, Creatinine $0.51(P=0.002)$, Glucose 1.21 $(P=0.046), \mathrm{iCa}^{2+} 0.10(P>0.05), \mathrm{K}^{+} 1.89(P>0.05), \mathrm{Na}^{+} 0.51(P>0.05), \mathrm{TCO}_{2}-0.2(P>0.05), \mathrm{pH}-6.08$ $(P>0.05)$, and Lactate $-3.03(P>0.05)$. The adjusted $\mathrm{R}^{2}$ represents goodness of fit of the regression. 
This dramatic conversion of glucose to lactate is interesting because the FF contained nearly arterial blood $\mathrm{pO}_{2}$ levels, yet the cells seemed to be utilizing glycolysis instead of oxidative phosphorylation. Nonetheless, the combined increases in lactate and $\mathrm{pCO}_{2}$ likely resulted in the reduced $\mathrm{pH}$ in FF. Similarly, the higher metabolism increased creatinine significantly across time $(P=0.026)$. As a closed and avascular microenvironment, the metabolic activities are fully reflected in the metabolite levels across time.

One of the objectives of this study was to determine if blood parameters could be used to estimate changes in FF. We calculated the correlations for nine parameters (Fig. 7) and found that glucose $(P=0.046)$, creatinine $(P=0.02)$, and $\mathrm{Cl}^{-}(P=0.02)$ were significantly and positively correlated. While not significant, a few parameters such as $\mathrm{iCa}^{2+}, \mathrm{TCO}_{2}, \mathrm{pH}$, and lactic acid were negatively correlated.

\section{Oviductal and uterine fluids}

Oviductal and uterine fluids visually varied in thickness and clarity, most likely due to different cellular debris contents. The visual characteristics were not correlated to times of sample collection. When samples contained large amounts of debris, the iSTAT failed to make a determination (producing $<>$ to indicate failure of measurement), or the values were higher than the upper limit of detection. We, therefore, were not able to collect data from all fluids on all parameters. The number of samples that gave successful readings is included in Table 1 for each time point and parameter. Across time points (Table 1), significant changes were observed in oviductal $\mathrm{Cl}^{-}(P=0.002), \mathrm{TCO}_{2}(P=0.005)$ and glucose $(P=0.049) ;\left(\right.$ Fig. 8), as well as uterine $\mathrm{Na}^{+}$ $(P=0.0001), \mathrm{Cl}^{-}(P=0.0006)$, and creatinine $(P=0.002)$. 
Table 1. Levels ( \pm SEM) of electrolytes and metabolites in OF and UF (numbers of animals at each time point are in brackets)

\begin{tabular}{lccccc}
\hline Groups & $\mathbf{N a}^{+}(\mathbf{m M})$ & $\mathbf{C l}^{-}(\mathbf{m M})$ & $\mathbf{T C O}_{2}(\mathbf{m M})$ & $\begin{array}{c}\text { Urea Nitrogen } \\
(\mathbf{m g} / \mathbf{d L})\end{array}$ & $\begin{array}{c}\text { Creatinine } \\
(\mathbf{m g} / \mathbf{d L})\end{array}$ \\
\hline Oviductal Fluid & & & & \\
$\mathbf{2 4} \mathbf{~ h}$ & $103.5 \pm 3.5(6)$ & $96.5 \pm 9.5(4)$ & $15 \pm 10(6)$ & $19.5 \pm 4.5(3)$ & $4.6 \pm 4.4(6)$ \\
$\mathbf{4 8 ~ h}$ & $106.5 \pm 4.5(4)$ & $104 \pm 2(4)$ & $6.5 \pm 1.5(4)$ & $23 \pm 3(3)$ & $3.9 \pm 0.9(4)$ \\
$\mathbf{6 0 ~ h}$ & $110.5 \pm 2.5(4)$ & $111 \pm 3(4)$ & $6 \pm 1(4)$ & $21 \pm 3(4)$ & $1.55 \pm 0.4(4)$ \\
$\mathbf{7 2} \mathbf{~ h}$ & $115 \pm 15(6)$ & $108 \pm 9(3)$ & $15 \pm 1.5(2)$ & $16.5 \pm 6.5(3)$ & $2.25 \pm 1.7(6)$ \\
\hline $\mathbf{U t e r i n e ~ F l u i d ~}$ & & & & \\
$\mathbf{2 4} \mathbf{~ h}$ & $107.5 \pm 7.5(6)$ & $101 \pm 2(3)$ & $12 \pm 0.23(4)$ & $12 \pm 2(3)$ & $4.125 \pm 3.6(5)$ \\
$\mathbf{4 8 ~ h}$ & $113 \pm 1(4)$ & $98.5 \pm 1.5(4)$ & $25 \pm 1(3)$ & $14.5 \pm 0.5(4)$ & $9.65 \pm 0.3(4)$ \\
$\mathbf{6 0 ~ h}$ & $128 \pm 10(5)$ & $121 \pm 11(5)$ & $11 \pm 1(4)$ & $10.5 \pm 3.5(5)$ & $1.45 \pm 1.3(5)$ \\
$\mathbf{7 2} \mathbf{~ h}$ & $123 \pm 7(5)$ & $113.5 \pm 6.5(5)$ & $14.5 \pm 2.5(5)$ & $11.5 \pm 3.5(5)$ & $2 \pm 1.7(5)$ \\
\hline
\end{tabular}

\section{Oviductal Fluid}

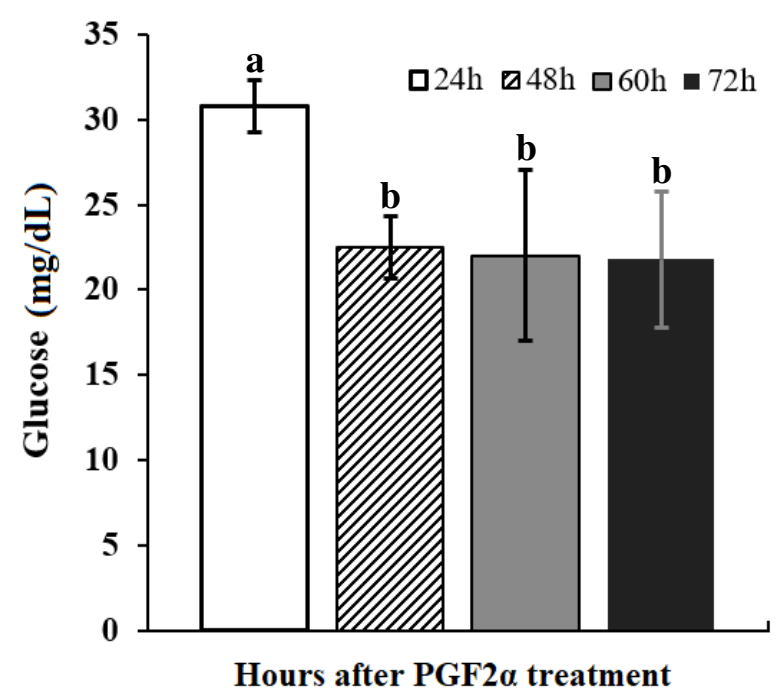

Fig 8. Glucose levels in OF significantly decreased $(P=0.049)$ across time points. 


\section{Differences across tissue fluids}

Although a parameter may vary significantly across time points within a tissue fluid, the

219 differences of a particular parameter across fluids were even greater (Fig. 9). To demonstrate these 220 differences, we pooled data within tissue fluids across time points. While $\mathrm{Na}^{+}$and $\mathrm{Cl}^{-}$were 221 relatively similar across the four different fluids, $\mathrm{K}^{+}$, urea nitrogen, and creatinine were drastically 222 different. Specifically, $\mathrm{K}^{+}$(Fig. 9b) was the highest in OF and UF. It is worthy to mention that the 223 iSTAT has a detection limit for $\mathrm{K}^{+}$at $9 \mathrm{mM}$ and multiple measurements for OF and UF were out 224 of range, showing readings as $>9 \mathrm{mM}$, and puzzlingly, still unattainable after dilutions. Therefore, 225 the $\mathrm{K}^{+}$levels in these two fluids could be much higher than $9.0 \mathrm{mM}$. Conversely, the $\mathrm{iCa}^{2+}$ was the 226 lowest in UF (Fig. 9b). Urea nitrogen and creatinine (Fig. 9c) were higher in OF than both blood 227 and FF and highest in UF, likely a result of differences in cellular activities. 
$\mathbf{a}$

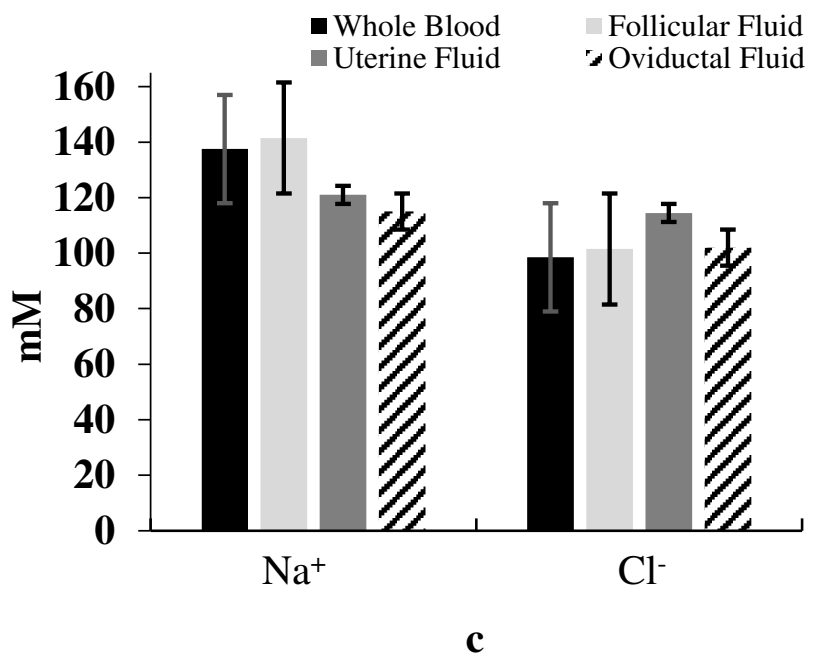

b

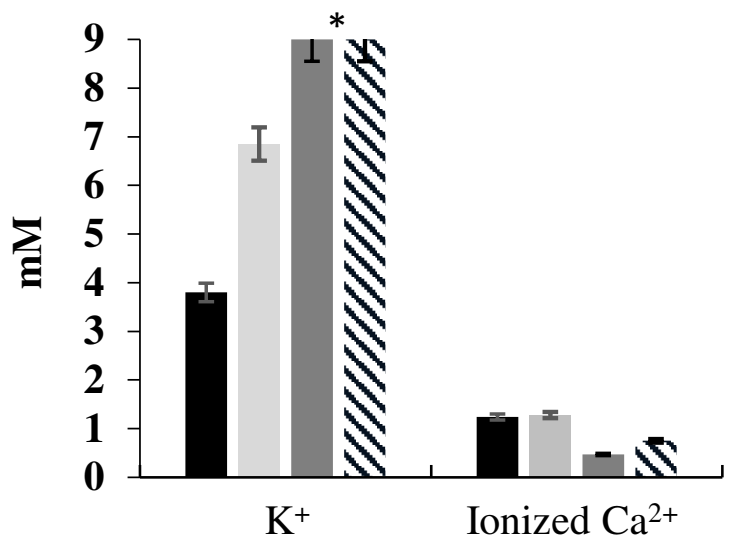

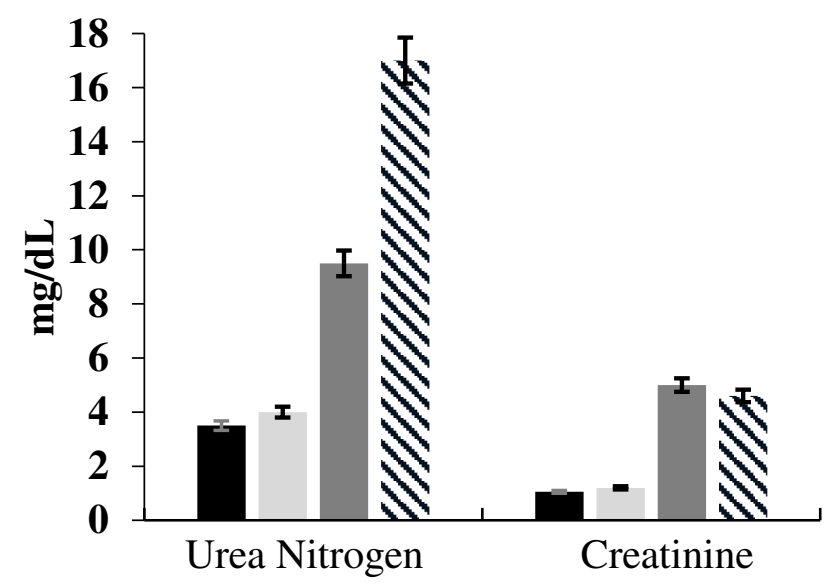

Fig 9. Levels $\left( \pm\right.$ SEM) of electrolytes and metabolites in the four tissue fluids. a) $\mathrm{Na}^{+}$and $\mathrm{Cl}^{-}$were relatively similar among fluids. b) $\mathrm{K}^{+}$is higher in FF than blood and highest in OF and UF. The ${ }^{*}$ is donated to the maximal reading of iSTAT $\left(\mathrm{K}^{+}>9.0 \mathrm{mM}\right)$ was reached in both OF and UF. The iCa ${ }^{2+}$ was lowest in UF. c) Urea Nitrogen was similar in blood and FF but higher in OF and highest in UF. Creatinine was higher in OF and UF than FF and blood. 
$\mathbf{a}$

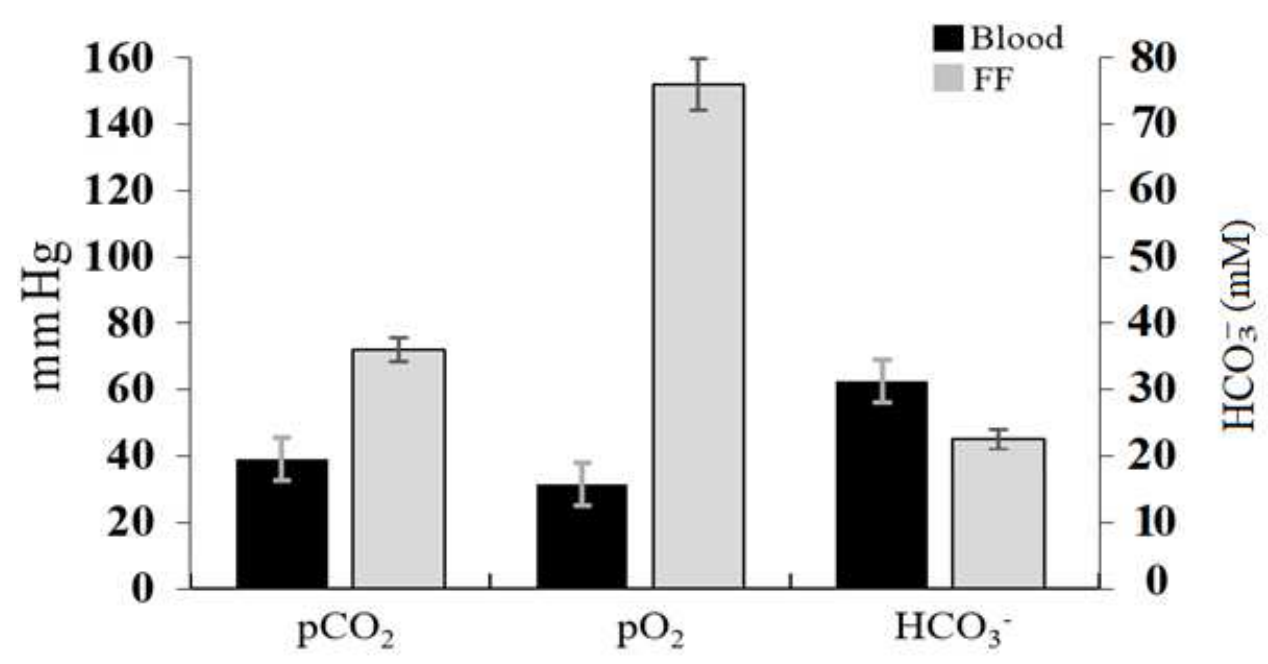

b

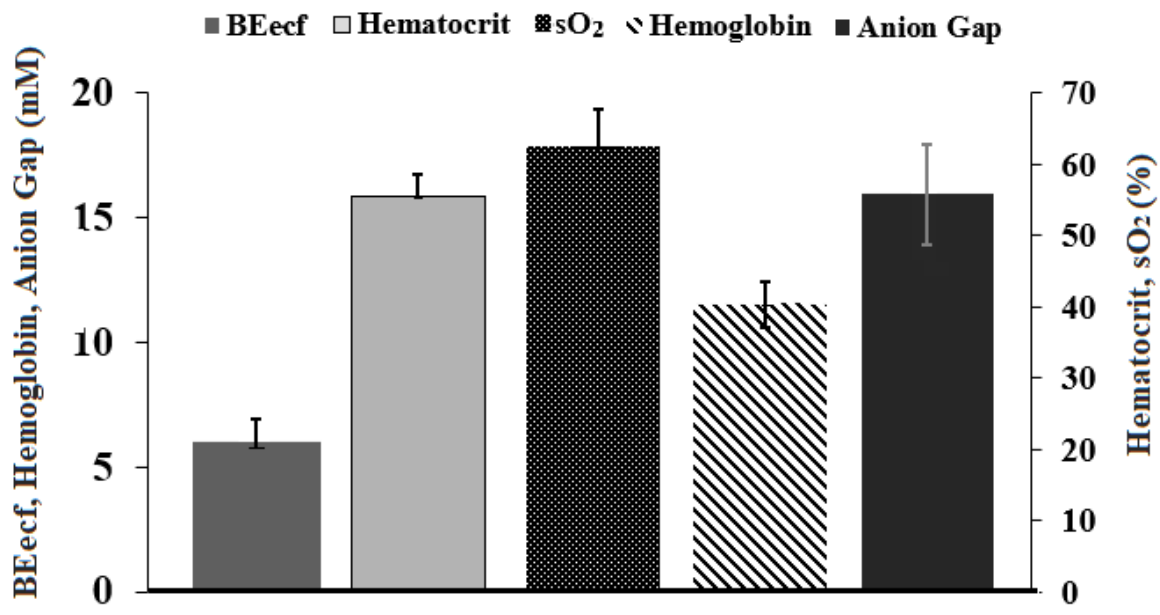

Fig 10. Pooled gas parameters in FF and blood (a) and pooled parameters in jugular blood samples (b).

When examining the pooled data on gases (Fig. 10), we found that in $\mathrm{FF}$ the $\mathrm{pCO}_{2}$ and

$237 \mathrm{pO}_{2}$ was approximately $5 \mathrm{X}$ and $2 \mathrm{X}$ higher than the levels in venous blood, respectively. These

238 suggest the follicle's strong mechanism in providing a near arterial blood $\mathrm{O}_{2}$ level to the developing 239 oocytes and the somatic cells in the follicles were highly metabolically active. The pooled 
240 parameters specific for the blood, such as hematocrit, hemoglobin and $\mathrm{sO}_{2}$ are also presented in 241 Fig. 10b. 


\section{Total protein and electrolytes}

While we found that serum maintained many parameters relatively constant for

245 homeostasis, for the first time we report that many parameters changed in fluids of the reproductive

246 tract as a result of luteolysis/CIDR removal and the subsequent LH surge/GnRH administration.

247 For example, all parameters except for $\mathrm{Cl}^{-}$in $\mathrm{FF}$ underwent significant changes $(P<0.05)$. Two out

248 of six parameters in OF and five out of five in UF also changed significantly across time points.

249 Several prior studies ${ }^{24,25,26}$ compared protein and electrolytes among blood and fluids of the

250 reproductive tracts. Few differences, however, were found likely because most of these studies

251 either used slaughterhouse materials ${ }^{25,26,27}$ or collected samples on different days of the estrous

252 cycle $28,29,15$. The closest study to ours was conducted by Berg et al. ${ }^{15}$ who used the iSTAT and

253 reported higher $\mathrm{K}^{+}$and low $\mathrm{Na}^{+}$in pre-ovulatory follicles than in dominant follicles. In oviductal

254 fluids, $\mathrm{Ca}^{2+29,30}$ underwent the most changes at estrus or a few days after estrus ${ }^{28}$. In the uterus,

255 Hugentobler et al. ${ }^{31}$ reported striking higher $\mathrm{K}^{+}$and lower $\mathrm{Cl}^{-}$and $\mathrm{Na}^{+}$on Day 14 than other days.

256 None of these prior studies, however, were designed to capture tissue fluid changes during the

257 window of in vivo oocyte maturation.

As reported previously by Hugentobler et al. ${ }^{31}$, we also found large differences in

259 electrolyte levels among different fluids, suggesting local regulation on secretion and excretion.

260 In all tissue fluids studied, $\mathrm{Na}^{+}$and $\mathrm{Cl}^{-}$are the major electrolytes and appear to be maintained at

261 comparable levels to preserve a charge-neutral environment. These two electrolytes also varied the

262 least from one fluid to another. For example, $\mathrm{Cl}^{-}$only varied $0.005,3$, and $11 \%$, respectively, from

263 blood to $\mathrm{OF}, \mathrm{FF}$, and UF. The $\mathrm{Na}^{+}$levels in the three tissue fluids also stayed close to those in the

264 blood and FF, varying less than $15 \%$ in UF and OF. The most varied electrolyte was $\mathrm{K}^{+}$, which 
265 was high in both UF or OF and was more than 52\% and 24\% lower in blood and FF, respectively.

266 It is known that $\mathrm{K}^{+}$levels in the blood are tightly regulated through kidney excretion, and the

267 concentration gradient for $\mathrm{K}^{+}$between serum and FF suggests an active inward transport ${ }^{27}$. The

268 high $\mathrm{K}^{+}$levels in the $\mathrm{OF}$ and UF could be a result of cellular breakdown and release of $\mathrm{K}^{+}$into the

269 surrounding fluids ${ }^{32}$. It is important to point out that electrolytes measured by the iSTAT were

270 within the ranges of those reported previously using other methods ${ }^{19,20,28}$. The concentration of $\mathrm{K}^{+}$

271 in OF and UF ranged between 3.5-14 mM among different studies with UF generally in the higher

272 range. Most OF and UF samples in our study reached the detection limit of the iSTAT (9 mM).

273 The concentration gradient across fluids could be greater if the actual readings were obtained.

274

\section{Tissue fluid gases and acid-base parameters}

Similar to electrolytes and total proteins, acid-base parameters and gases in bovine FF and

277 blood have also been reported by many studies in samples of different days of the estrous cycle or

278 in follicles of different developmental stages ${ }^{12,22,23,33-35}$. However, no report to date has specifically 279 characterized blood and FF parameters while oocytes undergo maturation. Here we found that 280 during this unique window, blood parameters were well-maintained, yet FF underwent significant 281 changes include $\mathrm{pH}, \mathrm{pCO}_{2}$, and $\mathrm{TCO}_{2}$. Although Indrova et al. ${ }^{12}$ collected $\mathrm{FF}$ at different times 282 post PG or superovulation, these were conducted in three different experiments, and no 283 comparisons could be made. Additionally, many studies used OPU for FF collection, which 284 increased pO2 due to the mixing of FF with air in the OPU tubing $34,36,37$.

To date, only one study documented $\mathrm{pH}, \mathrm{pO}_{2}$, and $\mathrm{pCO}_{2}$ in $\mathrm{FF}$ after timed initiation of 
287 hyperstimulation syndrome. This is normally conducted 10-12 h post-hCG injection ${ }^{38}$. As follicles 288 increase in size, $\mathrm{pO}_{2}$ dropped from 80 to $50-60 \mathrm{mmHg}$ and $\mathrm{pCO}_{2}$ increased from 35 to $50 \mathrm{mmHg}$, $289 \mathrm{pH}$ fell from 7.4 to 7.3. The trends of changes noted by Fischer et al. are similar to what we found 290 here and likely reflect the increase in the number of granulosa cells by the growing follicles ${ }^{18}$, 291 which in turn consumes more $\mathrm{O}_{2}$, produces more $\mathrm{CO}_{2}$ which lowers the $\mathrm{pH}$.

The data from the iSTAT collected here were consistent with those studied using different methods of determination, and under different reproductive statuses in that $\mathrm{pO}_{2}$ in $\mathrm{FF}$ was 294 significantly higher than that in venous blood. It is hard to explain, however, why Hussein et al. ${ }^{39}$ 295 found $\mathrm{pO}_{2}$ at 27 and $39 \mathrm{kPa}$ in spontaneous and induced preovulatory follicles. These $\mathrm{pO}_{2}$ levels 296 were higher than atmospheric $\mathrm{O}_{2}$ partial pressure of $20.95 \mathrm{kPa}$ (assuming the air contains $20.95 \%$ oxygen) and other reported atrial blood $\mathrm{pO}_{2}$ levels in the bovine.

\section{Carbohydrate substrates and metabolites}

We found eight prior studies which documented bovine FF glucose and most also reported lactate levels. However, all except for one used ovaries from slaughterhouses and large variations both within and among studies were found in the levels of glucose (25-96 mg/dL) and lactate (5.5-

304 dominant and pre-ovulatory but did not find many changes between them in either glucose or lactate. Although Leroy et al. ${ }^{24}$ used cows of knowns stage post-partum, it is unclear what stages

306 the follicles belonged to. Our data that glucose decreased while lactate increased after 307 luteolysis/LH surge are the first such finding. Because no prior studies contained information on the precise stage of follicular development, we are not able to compare our data to prior studies 
with the exception that our data on glucose and lactate from the iSTAT are within the prior reported ranges.

Similarly, no prior reports can be used as references for our data on glucose and lactate in OF because the two prior studies also used slaughterhouse materials. Lamy et al.$^{44}$ reported glucose at 2.3-3.5 mM (or $41-63 \mathrm{mg} / \mathrm{dL}$ ) in OF. Also using slaughterhouse materials, Jordaens et al. ${ }^{45}$ reported glucose in OF at $40 \mathrm{mg} / \mathrm{dL}$ and in blood at $110 \mathrm{mg} / \mathrm{dL}$. These ranges are similar to the data we found in both blood and OF.

Urea nitrogen levels were similar in blood and follicular fluid at $3.50 \pm 0.03$ and $4 \pm 0.11$ $\mathrm{mg} / \mathrm{dL}$, but highest in oviductal fluid at $17 \pm 1.28 \mathrm{mg} / \mathrm{dL}$, which was higher than the levels in uterine fluid at $9.50 \pm 0.73 \mathrm{mg} / \mathrm{dL}$. Equally drastically different among the four fluids was creatinine, which was similar in follicular fluid and blood $1.20 \pm 0.04$ and $1.05 \pm 0.04 \mathrm{mg} / \mathrm{dL}$, respectively, but $5 \pm 0.81$ and $4.60 \pm 0.42 \mathrm{mg} / \mathrm{dL}$ in uterine and oviductal fluid, respectively. We found a number of prior studies in which BUN/urea or creatinine was determined in bovine follicular fluid. Using slaughterhouse ovaries slaughterhouse materials, Iwata et al. ${ }^{25}$, Tabatabaei et $\mathrm{al}^{41}$, Kor et al. ${ }^{42}$, and Leroy et al. ${ }^{26}$ reported urea ranged between $2-20 \mathrm{mg} / \mathrm{dL}$ in follicles of different sizes as well as in blood. However, due to the lack of pre-slaughter information on the animals, it is unclear at what physiological stage these samples were obtained. Using post-partum cows and comparing urea in FF and blood, Leroy et al. ${ }^{26}$ reported similar values between these two fluids. The range of urea in FF and blood found in our study are within the ranges of those reported previously especially those by Leroy et al. ${ }^{26}$ using post-partum cows. Creatinine levels in FF were relatively more consistent in prior studies. Using slaughterhouse materials ${ }^{25,42,43,43}$ all reported creatinine at $\sim 1.5 \mathrm{mg} / \mathrm{dL}$ in FF of different sizes. Our data using precisely timed samples 
331 were within the ranges of prior data in both blood and FF although no prior study could be

332 referenced for the significant changes we observed after luteolysis and GnRH injection.

We found only one prior study which reported urea level in OF and no data on urea or creatinine levels in UF. Kenny et al. ${ }^{20}$ reported that OF urea was $\sim 6 \mathrm{mM}$ at standing heat. Our data in OF ranged from $16.5-23 \mathrm{mg} / \mathrm{dL}$ or $2.8-4 \mathrm{mM}$ and changed significantly across time. This is the first time multiple, time-lapsed data are reported and yet can't be compared to prior literature.

\section{Off-label use of iSTAT in tissue fluids other than the human blood}

The iSTAT has been validated for the determination of $\mathrm{pH}, \mathrm{pCO}_{2}, \mathrm{pO}_{2}$, total $\mathrm{CO}_{2}$, oxygen saturation, base excess, $\mathrm{HCO}_{3}^{-}, \mathrm{Na}^{+}, \mathrm{K}^{+}$, ionized $\mathrm{Ca}^{2+}$, hematocrit, and hemoglobin concentrations $^{14-16}$ in cattle blood against conventional instruments. The convenient handheld device has also been used for bovine follicular fluids ${ }^{15}$. While it is optimized for levels in human blood, in our hands we found it effective in most measurements of the CG4+ and CHEM8+ cartridges in bovine blood and follicular fluids. The parameters successfully detected by the iSTAT are within the ranges reported in prior studies using other instrumentations, although prior data were from slaughterhouse materials or different days of the estrous cycle.

It is worthy to mention that we also tried to use these cartridges of the iSTAT in uterine and oviductal fluids but many results, such as $\mathrm{pO}_{2}, \mathrm{pCO}_{2}, \mathrm{HCO}_{3}{ }^{-}$, and other parameters from $\mathrm{CG} 4+$ cartridge, could not be obtained, likely due to interference by cellular debris in these samples. Most samples were so thick that even we inverted the cartridges to allow gravity to help the sample pass through the narrow capillary channel, the instrument still failed to produce readings. Other 
352 measurement failures were caused by out-of-range levels. The iSTAT is designed for human blood

353 and the detection ranges were optimized for this sole purpose. For example, the maximum

354 detection limit for $\mathrm{K}^{+}$is $9 \mathrm{mM}$. However, multiple oviductal and uterine fluids gave the reading of

$355>9 \mathrm{mM}$. Strangely enough, diluting the samples with deionized water did not solve the problem.

356 The previously reported oviductal and uterine $\mathrm{K}^{+}$levels were 6 and 9-13 mM, respectively ${ }^{31}$. While

357 we obtained good and consistent readings in blood and follicular fluids for ions, gases, and 358 metabolites, the utility of the iSTAT especially in combination with the CG4+ cartridge in 359 oviductal and uterine fluids is limited.

\section{CONCLUSION}

This is the first study that characterized changes in components of the blood and fluids of 363 the reproductive tracts during the window of final follicular development and oocyte maturation. 364 The data revealed the in vivo microenvironment presented to the oocyte for competence in 365 fertilization and embryonic development. Moreover, this is also the first report to compare 366 parameters across four different fluids using the same groups of animals. The data presented here 367 provide invaluable information for the improvement of in vitro oocyte maturation conditions and 368 references to the reproductive processes. 


\section{ACKNOWLEDGEMENTS}

This study was supported by grants (W4171 and 58-8042-5-047) from the USDA to XCT.

371 Dr. Omer Faruk Gungor was supported by a scholarship from the Turkish Government (2219-

372 TUBITAK). We are indebted to Dr. Thomas Martin of Quinnipiac University for sharing the

373 iSTAT analyzer, Dr. Tim Moore and Hao Wu of the UConn Statistics Department for data analysis,

374 Mr. Gregory Payne of Abbott Point of Care for technical support, the UConn farm staff, Animal

375 Science Compliance Coordinator Sharon Aborn, the Attending Veterinarian Dr. Curtis

376 Schondelmeyer, the New England Meat Company, and the Tufts Ambulatory Service.

\section{CONFLICT OF INTEREST}

The authors declare no conflict of interest.

\section{AUTHOR CONTRIBUTIONS}

Omar Gungor and Saleh Salman have contributed equally to this research study. They planned the research protocol, hypothesized the study idea, designed the experiments, managed farm animal procedures and data collection, ran statistical analysis, and revised the whole manuscript. Saurav Ranjitkar and Delong Zhang have assisted in samples collections procedures and statistical analysis, and manuscript writing. Dr. Xiuchun (Cindy) Tian is the supervisor and corresponding author of this research. She planned the research protocol, provided and allocated 387 the USDA funding, hypothesized the study idea, managed samples collections, finalized the 388 experimental design, revised the statistical analysis and the whole manuscript. All authors 389 contributed to make an integrated work, revised, and agreed on the final manuscript style as 390 submitted. 


\section{REFERENCES}

392 1. Obuchi, T. et al. Comparative evaluation of the cost and efficiency of four types of sexing 393 methods for the production of dairy female calves. J. Reprod. Dev. 65, 345-352 (2019).

394 2. Lamb, G. C., Fontes, P. L. \& Oosthuizen, N. In vitro fertilization (IVF) versus multiple 395 396 ovulation embryo transfer (MOET): making the decision to use one or both. 136-142 (2019).

3. Leibfried-Rutledge, M. L., Critser, E. S., Eyestone, W. H., Northey, D. L. \& First, N. L. 398 Development potential of bovine oocytes matured in vitro or in vivo. Biol. Reprod. 36, 376-383 (1987).

4. Ealy, A. D., Wooldridge, L. K. \& McCoski, S. R. Board invited review: Post-transfer consequences of in vitro-produced embryos in cattle. J. Anim. Sci. 97, 2555-2568 (2019).

5. Ferré, L. B. et al. Review: Recent advances in bovine in vitro embryo production: reproductive biotechnology history and methods. Animal 14, 991-1004 (2020).

6. Smith, S. L. et al. Global gene expression profiles reveal significant nuclear reprogramming by the blastocyst stage after cloning. Proc. Natl. Acad. Sci. U. S. A. 102, 17582-17587 (2005).

7. Yuan, Y. et al. Quadrupling efficiency in production of genetically modified pigs through improved oocyte maturation. Proc. Natl. Acad. Sci. U. S. A. 114, E5796-E5804 (2017).

8. Hugentobler, S. A., Humpherson, P. G., Leese, H. J., Sreenan, J. M. \& Morris, D. G.

412 9. Fischer, B., Künzel, W., Kleinstein, J. \& Gips, H. Oxygen tension in follicular fluid falls with follicle maturation. Eur. J. Obstet. Gynecol. Reprod. Biol. 43, 39-43 (1992).

414 10. Orsi, N. M., Gopichandran, N., Leese, H. J., Picton, H. M. \& Harris, S. E. Fluctuations in 415 bovine ovarian follicular fluid composition throughout the oestrous cycle. Reproduction $416 \quad$ 129, 219-228 (2005).

417 11. Miller, D. J. Review: The epic journey of sperm through the female reproductive tract. Animal 12, s110-s120 (2018). 
12. Indrova, E. et al. Acid-base balance parameters of follicular fluid and venous blood in cattle. Acta Vet. Brno 89, 3-10 (2020).

13. Velazquez, M. A. et al. Sampling techniques for oviductal and uterine luminal fluid in cattle. Theriogenology 73, 758-767 (2010).

14. Peiró, J. R., Borges, A. S., Gonçalves, R. C. \& Mendes, L. C. N. Evaluation of a portable clinical analyzer for the determination of blood gas partial pressures, electrolyte concentrations, and hematocrit in venous blood samples collected from cattle, horses, and sheep. Am. J. Vet. Res. 71, 515-521 (2010).

15. Berg, M. C., Beaumont, S. E., Peterson, A. J. \& Berg, D. K. A procedure combining iSTAT analysis with OPU to study bovine follicular environments. Reprod. Fertil. Dev. 17, 318-319 (2005).

16. Yildirim, E., Karapinar, T. \& Hayirli, A. Reliability of the i-STAT for the determination of blood electrolyte (K+, Na+, and CI-) concentrations in cattle. J. Vet. Intern. Med. 29, 388-394 (2015).

17. Bó, G. A., Baruselli, P. S., Chesta, P. M. \& Martins, C. M. The timing of ovulation and insemination schedules in superstimulated cattle. Theriogenology 65, 89-101 (2006).

18. Tian, X. C., Berndtson, A. K. \& Fortune, J. E. Changes in levels of messenger ribonucleic acid for cytochrome P450 side- chain cleavage and 3 $\beta$-hydroxysteroid dehydrogenase during prostaglandin $\mathrm{F}(2 \alpha)$-induced luteolysis in cattle. Biol. Reprod. 50, 349-356 (1994).

19. Hugentobler, S. A., Morris, D. G., Sreenan, J. M. \& Diskin, M. G. Ion concentrations in oviduct and uterine fluid and blood serum during the estrous cycle in the bovine.

Theriogenology 68, 538-548 (2007).

20. Kenny, D. A. et al. Effect of elevated systemic concentrations of ammonia and urea on the metabolite and ionic composition of oviductal fluid in cattle. Biol. Reprod. 66, 1797-1804 (2002).

21. Team, R. C. R: A language and environment for statistical computing. (2013).

22. Nagy, O., Kováč, G., Seidel, H. \& Weissová, T. The effect of arterial blood sampling sites on blood gases and acid-base balance parameters in calves. Acta Vet. Hung. 49, 331-340 (2001). 
23. Nagy, O., Seidel, H., Kovac, G. \& Paulikova, I. Acid-base balance and blood gases in calves in relation to age and nutrition. Czech J. Anim. Sci. 48, 61-68 (2003).

24. Leroy, J. et al. Metabolic changes in follicular fluid of the dominant follicle in highyielding dairy cows early post partum. Theriogenology 62, 1131-1143 (2004).

25. Iwata, H. et al. Effects of follicle size and electrolytes and glucose in maturation medium on nuclear maturation and developmental competence of bovine oocytes. Reproduction 127, 159-164 (2004).

26. Leroy, J. et al. Metabolite and ionic composition of follicular fluid from different-sized follicles and their relationship to serum concentrations in dairy cows. Anim. Reprod. Sci. 80, 201-211 (2004).

27. Gosden, R. G., Hunter, R. H. F., Telfer, E., Torrance, C. \& Brown, N. Physiological factors underlying the formation of ovarian follicular fluid. Reproduction 82, 813-825 (1988).

28. Paisley, L. G. \& Mickelsen, W. D. Continuous collection and analysis of bovine oviduct fluid: preliminary results. Theriogenology 11, 375-384 (1979).

29. Grippo, A. A., Henault, M. A., Anderson, S. H. \& Killian, G. J. Cation concentrations in fluid from the oviduct ampulla and isthmus of cows during the estrous cycle. J. Dairy Sci. 75, 58-65 (1992).

30. Wagter-Lesperance, L. et al. Feasibility of high immune response (HIR) technology as a health management tool to characterize immune response profiles of dairy cattle. in Udder Health and Communication (eds. Hogeveen, H. \& Lam, T. J. G. M.) 359-366 (Wageningen Academic Publishers, 2012). doi:10.3920/978-90-8686-742-4_69

31. Hugentobler, S. A. et al. Amino acids in oviduct and uterine fluid and blood plasma during the estrous cycle in the bovine. Mol. Reprod. Dev. Inc. Gamete Res. 74, 445-454 (2007).

32. Pogorelov, A. G., Smirnov, A. A. \& Pogorelova, V. N. High Potassium Concentration during Culturing of Early Mammalian Embryos: Normal or Extreme Situation? Bull. Exp. Biol. Med. 163, 163-168 (2017).

33. e Paula, L. A. de C., Andrzejewski, J., Julian, D., Spicer, L. J. \& Hansen, P. J. Oxygen and 
steroid concentrations in preovulatory follicles of lactating dairy cows exposed to acute heat stress. Theriogenology 69, 805-813 (2008).

34. Redding, G. P., Bronlund, J. E. \& Hart, A. L. The effects of IVF aspiration on the temperature, dissolved oxygen levels, and $\mathrm{pH}$ of follicular fluid. J. Assist. Reprod. Genet. 23, 37-40 (2006).

35. Tvedten, H., Kopcia, M. \& Haines, C. Mixed venous and arterial blood in bovine coccygeal vessel samples for blood gas analysis. Vet. Clin. Pathol. 29, 4-6 (2000).

36. Čech, S. et al. Limitations of ultrasound guided follicular aspiration for analysis of ovarian follicular fluid in dairy cattle. Acta Vet. Brno 80, 179-184 (2011).

37. Cech, S. et al. A new device for the aspiration of follicular fluid for acid-base balance analysis in cattle. Vet. Med. (Praha). 58, (2013).

38. Tomaževič, T. \& Meden-Vrtovec, H. Early timed follicular aspiration prevents severe ovarian hyperstimulation syndrome. J. Assist. Reprod. Genet. 13, 282-286 (1996).

39. Hussein, H. A. \& Aamer, A. A. Influence of different storage times and temperatures on blood gas and acid-base balance in ovine venous blood. Open Vet. J. 3, 1-7 (2013).

40. Nishimoto, H., Hamano, S., Hill, G. A., Miyamoto, A. \& Tetsuka, M. Classification of bovine follicles based on the concentrations of steroids, glucose and lactate in follicular fluid and the status of accompanying follicles. J. Reprod. Dev. 902020130 (2009).

41. Tabatabaei, S., Mamoei, M. \& Aghaei, A. Dynamics of ovarian follicular fluid in cattle. Comp. Clin. Path. 20, 591-595 (2011).

42. Kor, N. M., Khanghah, K. M. \& Veisi, A. Follicular fluid concentrations of biochemical metabolites and trace minerals in relation to ovarian follicle size in dairy cows. Annu. Res. Rev. Biol. 397-404 (2013).

43. Mimoune, N. et al. Metabolic profile comparison between follicular fluid and serum in normal cows and those affected by ovarian cysts. Maced. Vet. Rev. 42, 51-59 (2019).

44. Lamy, J. et al. Metabolomic profiling of bovine oviductal fluid across the oestrous cycle using proton nuclear magnetic resonance spectroscopy. Reprod. Fertil. Dev. 30, 10211028 (2018). 
505

506

507

45. Jordaens, L. et al. Non-esterified fatty acids in early luteal bovine oviduct fluid mirror plasma concentrations: An ex vivo approach. Reprod. Biol. 17, 281-284 (2017). 